ENTREPRENEURSHIP AND SUSTAINABILITY ISSUES

ISSN 2345-0282 (online) http://jssidoi.org/jesi/

2020 Volume 8 Number 2 (December)

http://doi.org/10.9770/jesi.2020.8.2(58)
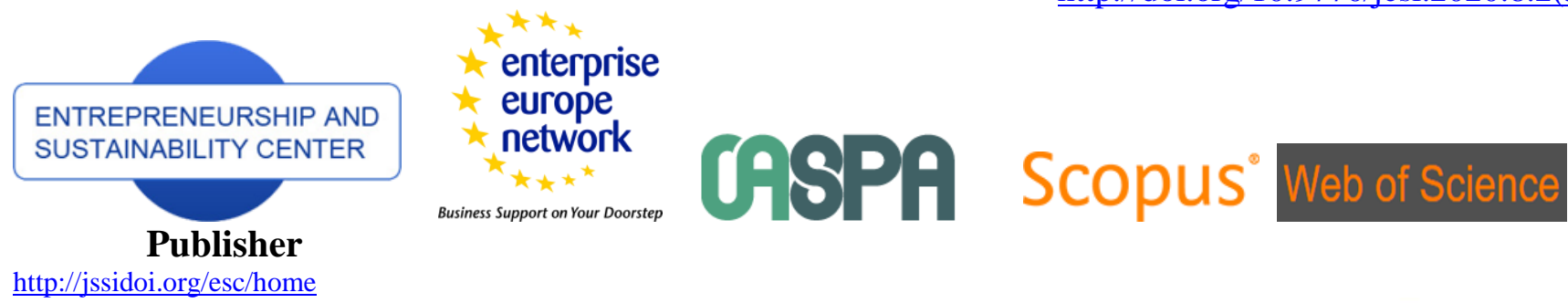

http://jssidoi.org/esc/home

\title{
THE FINANCIAL DEVELOPMENT AND THE REAL ESTATE MARKET IN VIETNAM: A STUDY IN CASE OF THE GLOBAL FINANCIAL CRISIS
}

\author{
My-Linh Thi Nguyen ${ }^{1}$, Toan Ngoc Bui ${ }^{2}$ \\ ${ }^{1}$ Faculty of Finance and Banking, University of Finance - Marketing (UFM), Ho Chi Minh City, Vietnam \\ ${ }^{2}$ Faculty of Finance and Banking, Industrial University of Ho Chi Minh City (IUH), Ho Chi Minh City, Vietnam \\ E-mails: ${ }^{1}$ ntmylinh@ufm.edu.vn; ${ }^{2}$ buingoctoan@iuh.edu.vn
}

Received 15 March 2020; accepted 29 September 2020; published 30 December 2020

\begin{abstract}
This paper is the first empirical evidence for the impact of financial development on the real estate market (REM) in Vietnam. The researchers utilize time series data in Vietnam in the period from 2004:Q3 to 2018:Q4. By using the autoregressive distributed lag (ARDL) model, the paper analyzes the impact of financial development through the banking system development and the stock market development on the REM in the short and long term. The research results are consistent with some previous studies as the impact of financial development on REM is found in the short and long term, and the impact is mainly positive. In particular, the impact of the banking system development on the REM is stronger than the impact of the stock market development on the REM. In addition, the paper also achieves great success in discovering the negative impact of the global financial crisis on the In particular, the impact of the banking system development on the REM is stronger than the impact of the stock market development on the REM in the short and long term, which is a new discovery compared to the previous studies. These findings are significant for the In particular, the impact of the banking system development on the REM is stronger than the impact of the stock market development on the REM in the economies all over the world, especially for a developing country like Vietnam.
\end{abstract}

Keywords: ARDL; financial development; financial crisis; real estate; Vietnam

Reference to this paper should be made as follows: Nguyen, M.L.T., Bui, T.N. (2020). The financial development and the real estate market in Vietnam: A study in case of the global financial crisis. Entrepreneurship and Sustainability Issues, 8(2), 960-971. http://doi.org/10.9770/jesi.2020.8.2(58)

JEL Classifications: E21, E44, R31

\section{Introduction}

The income variance around the world can be explained through the differences in the financial development across countries (Buera, Kaboski, \& Shin, 2011; Buera \& Shin, 2013). Accordingly, collateral used in loan agreements plays an important role. Indeed, in the countries with efficient financial development, solid development of banking system and stock market, financial services will be better than the countries with poor financial development (Bencivenga, Smith, \& Starr, 1995; Esso, 2010; King \& Levine, 1993; Bui, 2020). 


\section{ENTREPRENEURSHIP AND SUSTAINABILITY ISSUES}

ISSN 2345-0282 (online) http://jssidoi.org/jesi/ 2020 Volume 8 Number 2 (December) http://doi.org/10.9770/jesi.2020.8.2(58)

Therefore, in the countries with efficient financial development, capital can be accessed from the stock market or the banking system (including mortgage of real estate for loans) (Nguyen, Xuan, \& Bui, 2020). In the countries with poor financial development, the access to capital is mainly through real estate mortgages, which contributes to the decrease in financial market imperfections (Lim, 2018; Bui, 2019). The access to capital from the banking system or from the stock market helps households and enterprises to increase the capital for consumption and investment. Meanwhile, real estate is considered as both an investment and consumer goods (Kapopoulos \& Siokis, 2005). Therefore, financial development could bring about an increase in real estate prices, possibly even forming the bubble phenomenon in the REM (Lim, 2018). However, a poorly supervised financial system may be vulnerable to crisis (Moshirian \& Wu, 2012). The global financial crisis (which appeared in late 2007) is a testament to this and has a substantial impact on the REM (Antonakakis \& Florosc, 2016; Nguyen \& Bui, 2019). The global financial crisis can increase the risk in the capital market, causing negative impacts on the REM (Golob, Bastic, \& Psunder, 2012). Therefore, financial development and the global financial crisis can have a dramatical effect on the REM. However, there are a small number of studies which focus on the analysis of the impact of financial development on the REM, like the study by Lim (2018). Almost no research has extended the analysis of the impact of the global financial crisis on the REM. For this reason, the researchers carried out this study to create the first empirical evidence for the impact of financial development on the REM in case of the global financial crisis. Especially, the research data were collected in Vietnam, a developing country with the primary access to capital from real estate mortgages; accordingly, the impact of financial development on the REM may have its own characteristics, different from the research results in developed countries.

\section{Literature review}

Financial development might be defined as the development of the aggregate size of the financial sector and the efficiency of individual components in the financial sector. The participants in the financial sector playing an important role include central banks, commercial banks, finance companies, insurance companies, stock markets, pension funds, and other institutions in the financial market (Zaman, Izhar, Khan, \& Ahmad, 2012). Therefore, financial development includes both stock market development and banking system development (Pradhan, Arvin, Hall, \& Bahmani, 2014). The impact of financial development on the REM is expressed through the theory of wealth effect. The wealth effect has long been mentioned in the studies by Friedman (1957), Ando and Modigliani (1963). Recently, this effect has been mentioned a lot in empirical studies, especially in developed countries. According to the wealth effect theory, consumption is a function of total assets and disposable income. Total assets and income have a positive impact on consumer spending. Total assets include financial assets (stocks, bonds), real estate and other assets. Real estate is considered as both an investment and consumer goods (Kapopoulos \& Siokis, 2005). The wealth effect suggests that the wealth of households and enterprises will determine their consumption and investment behavior. Financial development will increase the value of wealth (assets and income) of households and enterprises. They will feel richer, which leads to the increase in spending and investment. As a result, the demand for housing and the investments in the REM have also increased, which will increase real estate prices, contributing to the development of the REM. In contrast, when financial development declines, the wealth of households and enterprises decreases. To ensure safety in the long-term and balance revenues and expenditures, they will cut down on spending and investment, resulting in the decrease in the REM. Overall, financial development has a significant impact on the REM.

Recently, Lim (2018) has indicated that the growth rates of real estate prices in the countries with efficient financial development are lower than in the countries with poor financial development. This is because in the countries with poor financial development, loans are mainly through real estate mortgages, which contributes to the decrease in financial market imperfections. This finding is consistent with the previous views of Shen (2013), Beck, Georgiadis, and Straub (2014), Mallick, Matousek, and Tzeremes (2016). In addition, some views argue that there is a positive impact of banking system development (which is measured through the ratio of the domestic credit to the private sector to GDP) on the REM, for example, in the studies by Bunda and Zorzi (2010), 


\section{ENTREPRENEURSHIP AND SUSTAINABILITY ISSUES}

ISSN 2345-0282 (online) http://jssidoi.org/jesi/

2020 Volume 8 Number 2 (December)

http://doi.org/10.9770/jesi.2020.8.2(58)

Hott (2011), Huang, Leung, and Qu (2015), Shen, Lee, Wu, and Guo (2016). Simultaneously, some studies also found the positive effect of stock market development (measured through the stock index) on the REM, for instance, in the studies by Ibrahim (2010), Ni and Liu (2011), Tsai, Lee, and Chiang (2011), Ding, Chong, and Park (2014), Lean and Smyth (2014), Huang et al. (2015).

The wealth effect also refers to the influence of the macro-economy on the aggregate demand in the market, including the demand for real estate. This is because the macro-economy has an impact on the wealth of households and enterprises. When the macro economy is beneficial, households and enterprises have many favorable conditions to increase the value of their wealth, which leads to the increase in the demand for housing and the investment in the REM. In view of this, Ibrahim (2010) found the positive impact of economic growth and consumer price index on the REM during the period of 1995:Q1-2006:Q4. In addition to domestic macroeconomic factors, the global financial crisis also has a significant impact on the REM. In fact, the global financial crisis may increase the risks in capital markets, causing negative impacts on the REM (Golob et al., 2012). The global financial crisis has enhanced worries for policy-makers in emerging countries, especially worriesabout the risk of a crisis in the REM in these countries (Zhang, Cai, Liu, \& Kutan, 2016). In case of the crisis in the REM, real estate prices will decline, the ability to pay bank loans will be reduced (due to unpaid real estate loans and collateral not enough to pay off the loans), which may lead to the arrival of a financial crisis (Zhao, Zhan, Jiang, \& Pan, 2017).

\section{Data and methodology}

Regarding the research data, the authors conducted data collection in Vietnam, which is a developing country with a relatively young real estate market and limited financial development. The research data were collected by the authors on a quarterly basis in the period from 2004:Q3 to 2018:Q4. The authors were only able to collect the data in this period because the Vietnamese real estate market was officially established after Vietnam's 2003 Land Law came into effect on July $1^{\text {st }}$, 2004. Therefore, the General Statistics Office of Vietnam is the only organization that publishes the data on the Vietnamese real estate market and these data were published on a quarterly basis in the period from 2004:Q3 to 2018:Q4.

The paper analyzed the impact of financial development on the REM, with the use of the ARDL model proposed by Pesaran, Shin, and Smith (2001). The ARDL model was also used in the study by Lean and Smyth (2014). The ARDL model has the advantage of being appropriate for empirical studies using time series data with a small number of observations and in the case that the data series are not stationary at the same level I(0) nor I(1), but no variable is stationary in the differential series I(2) (Tursoy \& Faisal, 2016).

The researchers measured the REM through the index of the REM growth announced by the General Statistics Office of Vietnam. For financial development, we measured it through the banking system development (domestic credit to the private sector to GDP - DCP) and the stock market development (Vietnam stock index SI). In particular, the authors measured the DCP variable thanks to the findings in the studies by Bunda and Zorzi (2010), Hott (2011), Huang et al. (2015), Shen et al. (2016), Lim (2018). Regarding the SI variable, the authors measured this variable thanks to the research results of Ibrahim (2010), Ni and Liu (2011), Tsai et al. (2011), Ding et al. (2014), Lean and Smyth (2014), Huang et al. (2015). Moreover, the researchers added the variable of the global financial crisis to the study to create novelty compared to the previous studies. According to Hui and Chan (2014), the global financial crisis began in August 2007. This financial crisis might last until March 2013 (Cayon, Thorp, \& Wu, 2017). Therefore, the financial crisis (FC) was measured by the dummy variable; FC receives a value of 1 for the period of the global financial crisis (from 2007:Q3 to 2013:Q1) and receives a value of 0 for the remaining periods. 
Accordingly, the model of the impact of financial development on the REM in Vietnam has the following equation:

$$
\Delta R E M_{t}=\alpha_{0}+\sum_{j=1}^{k} \lambda_{1} \Delta R E M_{t-j}+\sum_{j=0}^{k} \lambda_{2} \Delta D C P_{t-j}+\sum_{j=0}^{k} \lambda_{3} \Delta S I_{t-j}+\sum_{j=0}^{k} \lambda_{4} \Delta F C_{t-j}+\sum_{j=0}^{k} \lambda_{5} \Delta G D P_{t-j}+\sum_{j=0}^{k} \lambda_{6} \Delta C P I_{t-j}+\beta_{1} R E M_{t-1}+\beta_{2} D C P_{t-1}+\beta_{3} S I_{t-1}+\beta_{4} F C_{t-1}+\beta_{5} G D P_{t-1}+\beta_{6} C P I_{t-1}+\varepsilon_{t}
$$

Or:

$$
\Delta R E M_{t}=\alpha_{0}+\sum_{j=1}^{k} \lambda_{1} \Delta R E M_{t-j}+\sum_{j=0}^{k} \lambda_{2} \Delta D C P_{t-j}+\sum_{j=0}^{k} \lambda_{3} \Delta S I_{t-j}+\sum_{j=0}^{k} \lambda_{4} \Delta F C_{t-j}+\sum_{j=0}^{k} \lambda_{5} \Delta G D P_{t-j}+\sum_{j=0}^{k} \lambda_{6} \Delta C P I_{t-j}+\phi E C M_{t-1}+\varepsilon_{t}
$$

\begin{tabular}{|c|c|c|c|}
\hline Variable name & Code & Source & How to measure \\
\hline \multicolumn{4}{|c|}{ Dependent variable } \\
\hline Real estate market & REM & GSO & $\begin{array}{l}\text { REM mainly focuses on business activities in the REM, including } \\
\text { three main areas: Commerce, leasing offices or houses, and } \\
\text { consultancy (brokerage). }\end{array}$ \\
\hline \multicolumn{4}{|c|}{ Independent variable } \\
\hline $\begin{array}{l}\text { Domestic credit to the } \\
\text { private sector }\end{array}$ & DCP & IMF & The domestic credit to the private sector to GDP. \\
\hline Stock index & SI & SSC & Logarithm of Vietnam stock index: $\log (\mathrm{VN}$-Index). \\
\hline Financial crisis & $\mathrm{FC}$ & $\begin{array}{l}\text { Author's } \\
\text { computation }\end{array}$ & $\begin{array}{l}\text { The dummy variable of the FC receives a value of } 1 \text { for the period of } \\
\text { the global financial crisis (from 2007:Q3 to 2013:Q1) and receives a } \\
\text { value of } 0 \text { for the remaining periods. }\end{array}$ \\
\hline \multicolumn{4}{|c|}{ Control variable } \\
\hline Economic growth & GDP & GSO & Quarterly growth of gross domestic product. \\
\hline Consumer price index & CPI & GSO & Quarterly growth of consumer price index. \\
\hline \multicolumn{4}{|c|}{$\begin{array}{l}\text { Note: } \\
\text { GSO: General Statistics Office of Vietnam. } \\
\text { IMF: International Monetary Fund. } \\
\text { SSC: State Securities Commission of Vietnam. }\end{array}$} \\
\hline
\end{tabular}

Table 1. Suggested research model

\section{Empirical results}

\subsection{Descriptive statistics}

The research data were collected on a quarterly basis in the period from 2004:Q3 to 2018:Q4, with the variables described in Table 2 below:

Table 2. Descriptive statistics

\begin{tabular}{|l|c|c|c|}
\hline \multicolumn{1}{|c|}{ Variable } & Mean & Min & Max \\
\hline REM & 0.0288 & -0.0134 & 0.0587 \\
\hline DCP & 0.2460 & 0.0798 & 0.6321 \\
\hline VN-Index & 566.4624 & 231.22 & 1094.08 \\
\hline FC & 0.3966 & 0 & 1 \\
\hline GDP & 0.0659 & 0.0314 & 0.0945 \\
\hline CPI & 0.0831 & 0 & 0.279 \\
\hline Note: VN-Index: Vietnam stock index. & & \\
\hline
\end{tabular}


Vietnam is a developing country, with a young stock market (officially operating on 28 July 2000); the banking system still plays a crucial role in providing credit to the financial market in Vietnam (Batten \& Vo, 2016). Therefore, the mortgage of real estate for bank loans is the main activity.

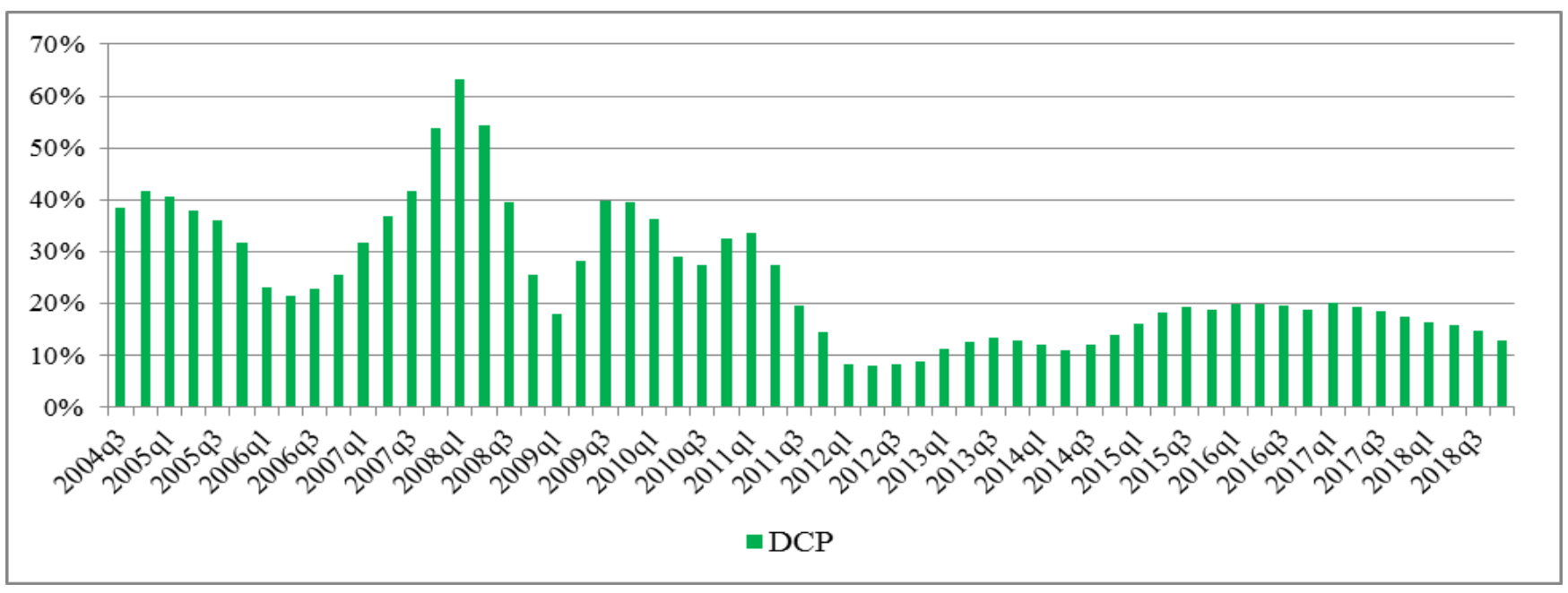

Figure 1. Growth of the domestic credit to the private sector (DCP)

DCP in Vietnam grew strongly in the first quarter of 2008, when the Vietnamese economy saw many positive signals with the expansion of production and business activities (Figure 1).

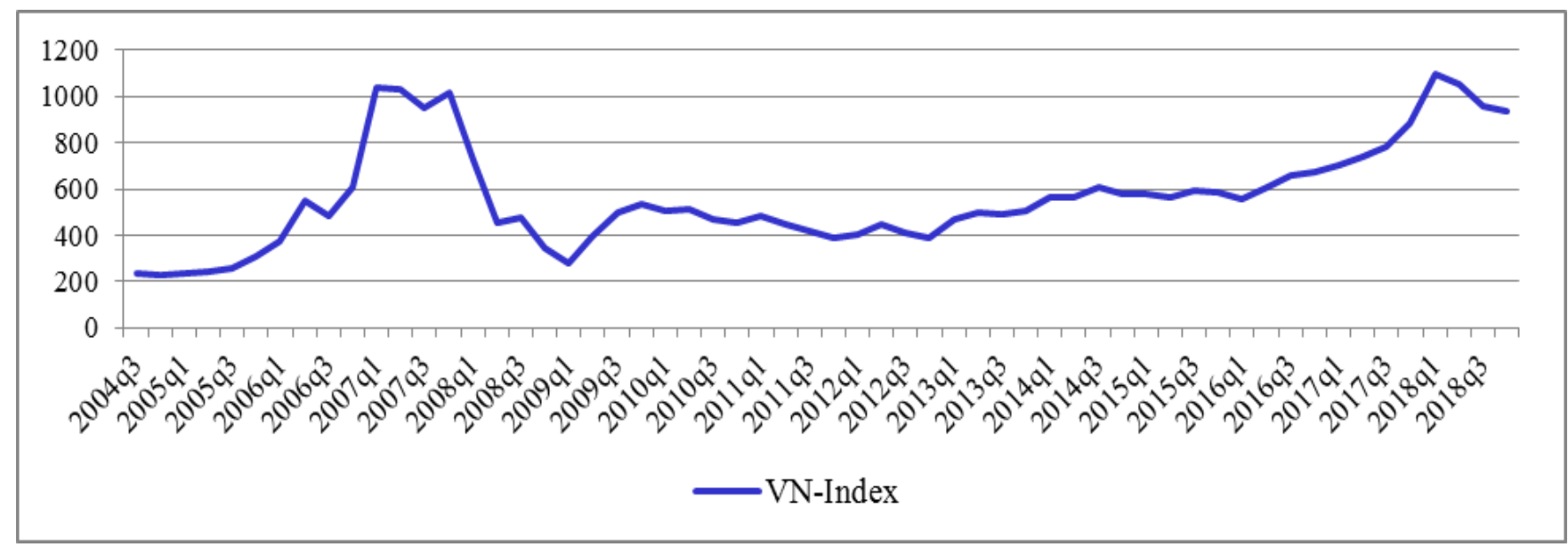

Figure 2. Vietnam stock index (VN-Index)

In 2007, with the positive signs from the fact that Vietnam officially became a member of the World Trade Organization (WTO), the Vietnam stock market grew hotly in the first quarter of 2007 (the stock index averaged 1035.589 points). Recently, Vietnam stock market peaked in the first quarter of 2018 (the stock index averaged 1094.08 points), exceeding the previous peak in the first quarter of 2007. 


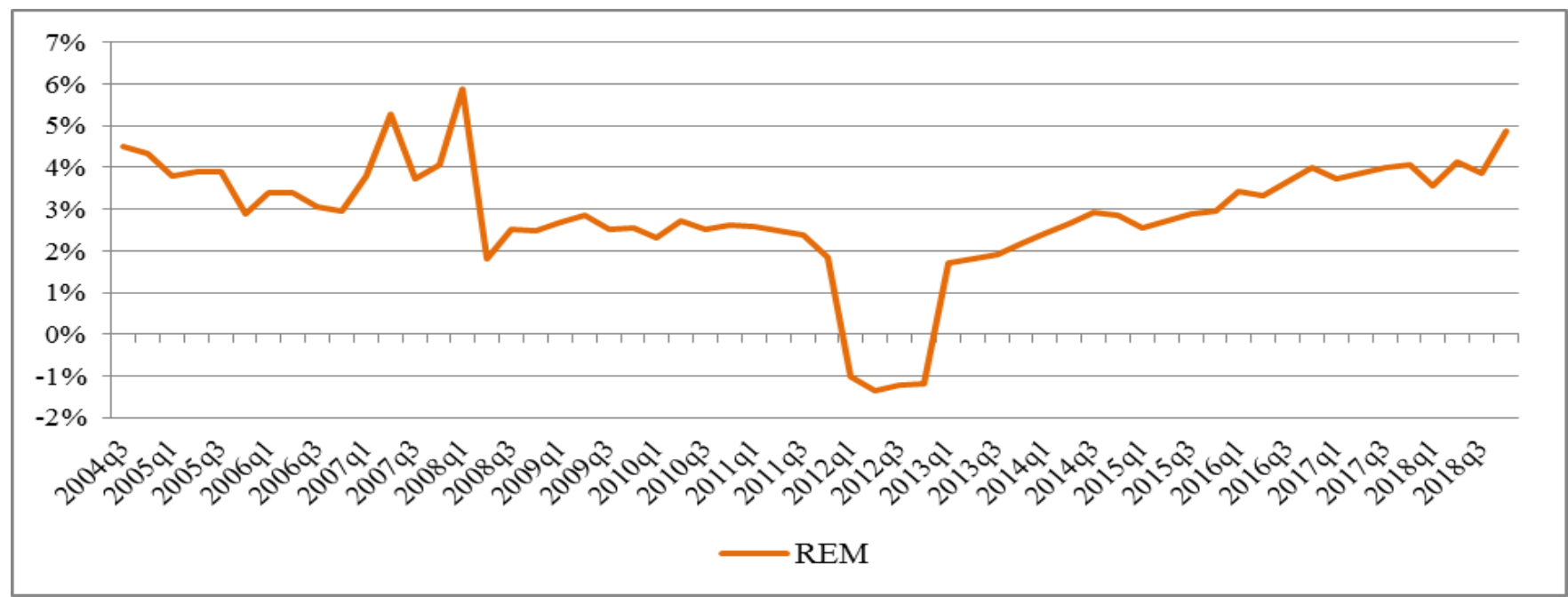

Figure 3. REM growth

With the hot growth from bank credit and the stock market, the capital into the REM amplified. This resulted in the high growth of the REM in the first quarter of 2008. However, after this period, with the negative impacts from the global financial crisis, the Vietnam REM plummeted. This decline lasted until the second quarter of 2012 because of the difficulties in accessing capital when the monetary policy tightened (Nguyen, Bui, \& Nguyen, 2019). Recently, the world and domestic economies have recovered, which has contributed significantly to promoting the REM to grow again (Figure 3).

\subsection{Unit root test}

Table 3. Results of unit root tests

\begin{tabular}{|l|c|c|c|c|c|}
\hline & REM & DCP & SI & GDP & CPI \\
\hline AT LEVEL & 0.1167 & 0.4706 & 0.3334 & $0.0449^{* * *}$ & 0.4612 \\
\hline AT $\Delta$ & $0.0000^{* * * *}$ & $0.0024^{* * *}$ & $0.0000^{* * *}$ & $0.0000^{* * *}$ & $0.0013^{* * *}$ \\
\hline Note ${ }^{* * *}$ and ${ }^{* * * *}$ indicate significance at the 5\% and 1\% level, respectively. \\
\hline
\end{tabular}

The results of stationarity test suggested by Dickey and Fuller (1979) show that the variable of GDP is stationary in the $\mathrm{I}(0)$. In the meantime, the remaining data series are stationary in the $\mathrm{I}(1)$ at the $1 \%$ significance level (Table $3)$.

\subsection{Cointegration test}

The research paper measures the lag of variables in the ARDL model through the Bayesian Information Criterion (BIC). Bisgaard and Kulahci (2011) argued that identifying the optimal lag according to BIC is better than normal criteria. Furthermore, the paper also utilizes the bound test method recommended by Pesaran et al. (2001) to test the cointegration between the data series.

Hypothesis $\mathrm{H}_{0}: \beta_{1}=\beta_{2}=\ldots=\beta_{\mathrm{n}}=0$ (there is no cointegration relationship between the data series).

Hypothesis $\mathrm{H}_{\mathrm{A}}: \beta_{1} \neq \beta_{2} \neq \ldots \beta_{\mathrm{n}} \neq 0$ (there is a cointegration relationship between the data series). 
Table 4. Results of the bound test of cointegration

\begin{tabular}{|c|c|c|}
\hline \multicolumn{3}{|l|}{$\mathrm{F}=5.871$} \\
\hline \multirow[b]{2}{*}{ p-value } & $\mathrm{I}(0)$ & $0.001^{* * * *}$ \\
\hline & $\mathrm{I}(1)$ & $0.006^{* * * *}$ \\
\hline
\end{tabular}

Table 4 shows that $\mathrm{F}$ is bigger than the $\mathrm{I}(1)$ proposed by Pesaran et al. (2001) at the $1 \%$ significance level. Therefore, there is a cointegration relationship between the data series at the $1 \%$ significance level.

\subsection{Results of coefficient estimation}

The analysis results regarding the impact of financial development on the REM according to the ARDL model are below:

Table 5. ARDL long-run and short-run results

\begin{tabular}{|l|c|c|}
\hline \multicolumn{1}{|c|}{ Variable } & Coef. & Prob. \\
\hline DCP & 0.1068 & $0.000^{* * *}$ \\
\hline SI & 0.0404 & $0.001^{* * *}$ \\
\hline FC & -0.0195 & $0.000^{* * * *}$ \\
\hline GDP & -0.1519 & 0.329 \\
\hline CPI & -0.0238 & 0.609 \\
\hline \multicolumn{2}{|c|}{ Short-run results } \\
\hline$\triangle$ DCP & 0.0981 & $0.002^{* * * *}$ \\
\hline$\triangle$ DCP(-1) & -0.0876 & $0.003^{* * *}$ \\
\hline$\triangle$ SI & 0.0280 & $0.002^{* * *}$ \\
\hline$\triangle$ FC & -0.0135 & $0.001^{* * *}$ \\
\hline$\triangle$ GDP & -0.1052 & 0.325 \\
\hline$\triangle$ CPI & -0.0165 & 0.608 \\
\hline ECM(-1) & -0.6923 & $0.000^{* * * *}$ \\
\hline Constant & -0.0611 & $0.009^{* * *}$ \\
\hline R-squared & \multicolumn{2}{|c|}{0.1319} \\
\hline White's test & \multicolumn{2}{|c|}{0.3839} \\
\hline Breusch-Godfrey LM test & \\
\hline Ramsey Reset test & Note: ${ }^{* * *}$ indicates significance at the $1 \%$ level. \\
\hline
\end{tabular}

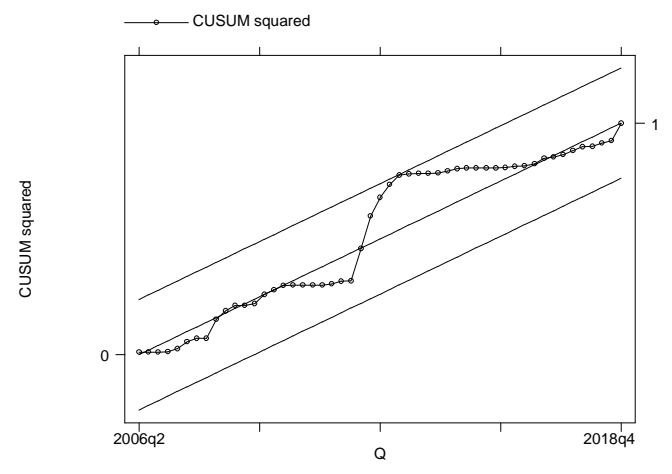

Figure 4. Plots of CUSUM squared statistics for coefficient stability tests 


\section{ENTREPRENEURSHIP AND SUSTAINABILITY ISSUES}

ISSN 2345-0282 (online) http://jssidoi.org/jesi/

2020 Volume 8 Number 2 (December)

http://doi.org/10.9770/jesi.2020.8.2(58)

White's test shows that the research model has no homoscedasticity. Breusch-Godfrey LM test shows that the research model has no serial correlation. The Ramsey Reset confirmed that the functional form of the model does not suffer from omitted variables. Simultaneously, the paper conducted stability tests of the model through the CUSUM squared. The stability test suggested by Brown, Durbin, and Evans (1975) indicates that the CUSUM squared is within the standard range at the 5\% significance level (Figure 4). Therefore, the research model has stability and appropriateness.

Table 5 shows that in the short and long term, the REM is impacted by financial development (DCP and SI) at the $1 \%$ significance level, and the impact is primarily positive. This impact is entirely consistent with the wealth effect theory. However, the REM is impacted greater by the DCP than by the SI. This is consistent with the reality because Vietnam is a developing country with the main capital into the REM stemming from the mortgage of real estate for loans. Therefore, it is understandable that the REM is strongly affected by the DCP. This result is consistent with the previous finding in the study by Lim (2018). In addition, at the $1 \%$ significance level, the researchers also find the negative impact of the FC on the REM in the short and long term. Meanwhile, the researchers have not found the statistically significant impact of GDP and CPI on the REM.

For the domestic credit to the private sector $(\mathrm{DCP})$ : In the short term, the DCP has a positive impact on the REM. However, with one lag, this direction tends to reverse. In the long term, the researchers also find the positive impact of the DCP on the REM. Therefore, the impact of the DCP on the REM is mainly positive. This suggests that the DCP plays an important role in increasing investments in the REM, thereby boosting the REM. This finding is consistent with the study by Bunda and Zorzi (2010), Hott (2011), Huang et al. (2015), Shen et al. (2016). Simultaneously, this finding is also consistent with the wealth effect theory. As a result, the DCP provided by the banking system may stimulate the development of the REM. However, if the capital in the REM increases excessively and is not strictly controlled, it can create a bubble phenomenon in the REM, and the occurrence of the global financial crisis in 2007 is a testament to this impact.

For the stock index (SI): In the short and long term, the SI has a positive impact on the REM at the $1 \%$ significance level. Therefore, when the stock market develops, investors in the stock market will increase their asset value and tend to increase the demand for housing and the investments in the REM. This will promote the development of the REM. This result is consistent with the previous findings in the studies by Ibrahim (2010), Ni and Liu (2011), Tsai et al. (2011), Ding at al. (2014), Lean and Smyth (2014), Huang et al. (2015). It can be said that the impact of the SI on the REM is completely consistent with the wealth effect theory.

For the financial crisis $(\boldsymbol{F C})$ : In the short and long term, the FC has a negative impact on the REM at the $1 \%$ significance level. Vietnam has achieved certain steps in the process of international integration. Therefore, it is inevitable that the REM is impacted negatively by the FC. When the global financial crisis appeared, the world and Vietnam economy faced many difficulties. The real estate transactions declined sharply and the real estate industry had difficulty in accessing capital. As a result, the REM would decline dramatically. The discovery of the statistically significant impact of the FC on the REM reflects the reality in Vietnam, and this is also a new finding of this research paper.

\section{Conclusions}

The paper shows the impact of financial development on the REM in both the short and long term, and the impact is mainly positive. In particular, the REM is impacted greater by the domestic credit to the private sector (DCP) than by the stock index (SI). This finding is completely consistent with the wealth effect theory. However, this finding represents the difference between Vietnam and developed countries, because the access to capital from the banking system plays a key role in developing countries like Vietnam. Simultaneously, with the analysis of the role of the global financial crisis, the paper achieves great success in finding the negative impact of the global 


\section{ENTREPRENEURSHIP AND SUSTAINABILITY ISSUES}

ISSN 2345-0282 (online) http://jssidoi.org/jesi/

2020 Volume 8 Number 2 (December)

http://doi.org/10.9770/jesi.2020.8.2(58)

financial crisis on the REM in the short and long term, which is the new finding of this paper compared to the previous studies. This paper is the first empirical evidence in Vietnam for the impact of financial development on the REM. In addition, it is the first study to examine the role of the global financial crisis when analyzing the impact of financial development on the REM. Accordingly, the research results bring practical value to Vietnam. Furthermore, the research results also have important implications for the REM in the world's economies, especially for developing countries like Vietnam.

The research results show that financial development has an impact on Vietnam's REM in the short and long term, and the impact is mainly positive. In addition, the researchers find out the negative influence of the global financial crisis on the REM in the short and long term. Therefore, the world economy and the domestic financial development play a principalrole in Vietnam's REM. Thanks to that, the researchers suggest some policy implications as follows:

- The government of Vietnam should closely monitor the world economic situation, together with the improvement in the forecasts of the world economic situation. Thereby, there will be a foundation to apply suitable policies to boost the development of the economy and the REM in a sustainable way. In particular, it is essential to take advantage of the opportunities created by international economic integration and simultaneously to have appropriate policies to limit the negative impacts of the world economy.

- The government of Vietnam should also have an efficient policy on financial development, making the most of capital resources in the economy to stimulate the development of the REM. In particular, the government of Vietnam should attach considerable importance to the credit capital from the banking system and the capital resource from the stock market. However, it is necessary that the REM should develop in a sustainable way, meeting the actual demand in the market, and avoiding the formation of bubbles in the REM. This is because when bubbles are formed in the REM, the REM will be at risk of recession in the future. This will lead to negative effects on the economy, and the global financial crisis is a testament to this issue.

- This paper has achieved definite success in finding the first empirical evidence for the impact of financial development on the REM in Vietnam. However, this study also faces major limitations when it is impossible to collect data for each locality in Vietnam. Therefore, the researchers cannot analyze the impact of financial development on the REM in each locality. Meanwhile, each locality in Vietnam has its own characteristics of financial development as well as those of the REM. This is also a remarkable direction for further studies.

\section{References}

Ando, A.; Modigliani, F. 1963. The Life Cycle Hypothesis of Saving: Aggregate Implications and Tests, American Economic Review, 103(1): 55-84. Retrieved from: https://www.econ.nyu.edu/user/violante/NYUTeaching/MTA/Spring14/Readings/ando_aer.pdf

Antonakakis, N.; Florosc, C. 2016. Dynamic interdependencies among the housing market, stock market, policy uncertainty and the macroeconomy in the United Kingdom, International Review of Financial Analysis, 44: 111-122. https://doi.org/10.1016/j.irfa.2016.01.006

Batten, J.A.; Vo, X.V. 2016. Bank risk shifting and diversification in an emerging market, Risk Management, 18(4): 217-235. https://doi.org/10.1057/s41283-016-0008-2

Beck, R.; Georgiadis, G.; Straub, R. 2014. The finance and growth nexus revisited, Economics Letters, 124(3): 382-385. https://doi.org/10.1016/j.econlet.2014.06.024

Bencivenga, V.R.; Smith, B.D.; Starr, R.M. 1995. Transaction costs, technological choice, endogenous growth, Journal of Economic Theory, 67(1): 53-117. https://doi.org/10.1006/jeth.1995.1069 


\section{ENTREPRENEURSHIP AND SUSTAINABILITY ISSUES}

ISSN 2345-0282 (online) http://jssidoi.org/jesi/

2020 Volume 8 Number 2 (December)

http://doi.org/10.9770/jesi.2020.8.2(58)

Bisgaard, S.; Kulahci, M. 2011. Time Series Analysis and Forecasting by Example. A John Wiley \& Sons, Inc., Publication, $163-164$.

Brown, R.L.; Durbin, J.; Evans, J.M. 1975. Techniques for Testing the Constancy of Regression Relationships Over Time, Journal of the Royal Statistical Society, 37(2): 149-192. Retrieved from: https://www.jstor.org/stable/2984889

Buera, F.J.; Kaboski, J.P.; Shin, Y. 2011. Finance and development: a tale of two sectors, American Economic Review, 101(5): 1964-2002. Retrieved from: https://www.aeaweb.org/articles?id=10.1257/aer.101.5.1964

Buera, F.J.; Shin, Y. 2013. Financial frictions and the persistence of history: a quantitative exploration, Journal of Political Economy, 121(2): 221-272. Retrieved from: https://www.jstor.org/stable/10.1086/670271

Bui, T.N. 2019. The Role of Financial Development in the Vietnam Economy, WSEAS Transactions on Business and Economics, 16: 471476. Retrieved from: https://www.wseas.org/multimedia/journals/economics/2019/a985107-854.pdf

Bui, T.N. 2020. How does Financial Development Affect the Employment? Evidence from Asean Countries, Journal of Management Information and Decision Sciences, 23(1): 1-6. Retrieved from: https://www.abacademies.org/articles/How-does-financial-developmentaffect-the-employment-evidence-1532-5806-23-1-174.pdf

Bunda, I.; Zorzi, M.C. 2010. Signals from housing and lending booms, Emerging Markets Review, 11(1): 1-20. https://doi.org/10.1016/j.ememar.2009.09.003

Cayon, E.; Thorp, S.; Wu, E. 2018. Immunity and infection: Emerging and developed market sovereign spreads over the Global Financial Crisis, Emerging Markets Review, 34: 162-174. https://doi.org/10.1016/i.ememar.2017.11.006

Dickey, D.A.; Fuller, W.A. 1979. Distribution of the Estimators for Autoregressive Time Series with Unit Root, Journal of the American Statistical Association, 74: 427-432. https://doi.org/10.1080/01621459.1979.10482531

Ding, H.; Chong, T.T.L.; Park, S.Y. 2014. Nonlinear dependence between stock and real estate markets in China, Economics Letters, 124(3): 526-529. https://doi.org/10.1016/j.econlet.2014.05.035

Esso, L.J. 2010. Re-examining the finance-growth nexus: Structural break, threshold cointegration and causality evidence from the ECOWAS, Journal of Economic Development, 35(3): 57-79. Retrieved from: http://www.jed.or.kr/full-text/35-3/3.pdf

Friedman, M. 1957. A Theory of the Consumption Function: A Study by the National Bureau of Economic Research. Princeton University Press, Princeton.

Golob, K.; Bastic, M.; Psunder, I. 2012. Analysis of Impact Factors on the Real Estate Market: Case Slovenia, Inzinerine Ekonomika (Engineering Economics), 23(4): 357-367. https://doi.org/10.5755/j01.ee.23.4.2566

Hott, C. 2011. Lending behavior and real estate prices, Journal of Banking \& Finance, 35(9): 2429-2442. https://doi.org/10.1016/j.jbankfin.2011.02.001

Huang, D.J.; Leung, C.K.; Qu, B. 2015. Do bank loans and local amenities explain Chinese urban house prices?, China Economic Review, 34: 19-38. https://doi.org/10.1016/j.chieco.2015.03.002

Hui, E.C.M.; Chan, K.K.K. 2014. The global financial crisis: Is there any contagion between real estate and equity markets?, Physica A: Statistical Mechanics and its Applications, 405: 216-225. https://doi.org/10.1016/j.physa.2014.03.008

Ibrahim, M.H. 2010. House price-stock price relations in Thailand: an empirical analysis, International Journal of Housing Markets and Analysis, 3(1): 69-82. https://doi.org/10.1108/17538271011027096

Kapopoulos, P.; Siokis, F. 2005. Stock and real estate price in Greece: wealth versus 'credit-price' effect, Applied Economics Letters, 12(2): 125-128. https://doi.org/10.1080/1350485042000307107

King, R.G.; Levine, R. 1993. Finance and growth: Schumpeter might be right, The Quarterly Journal of Economics, 108(3): 717-737. https://doi.org/10.2307/2118406 


\section{ENTREPRENEURSHIP AND SUSTAINABILITY ISSUES}

ISSN 2345-0282 (online) http://jssidoi.org/jesi/ 2020 Volume 8 Number 2 (December)

http://doi.org/10.9770/jesi.2020.8.2(58)

Lean, H.H.; Smyth, R. 2014. Dynamic interaction between house prices and stock prices in Malaysia, International Journal of Strategic Property Management, 18(2): 163-177. https://doi.org/10.3846/1648715X.2014.925006

Lim, T. 2018. Growth, financial development, and housing booms, Economic Modelling, 69: 91-102. https://doi.org/10.1016/j.econmod.2017.09.008

Mallick, S.; Matousek, R.; Tzeremes, N.G. 2016. Financial development and productive inefficiency: a robust conditional directional distance function approach, Economics Letters, 145: 196-201. https://doi.org/10.1016/j.econlet.2016.06.019

Moshirian, F.; Wu, Q. 2012. Banking industry volatility and economic growth, Research in International Business and Finance, 26(3): 428-442. https://doi.org/10.1016/j.ribaf.2012.01.004

Nguyen, M.L.T.; Bui, T.N. 2019. Stock market, real estate market, and economic growth: an ARDL approach, Investment Management and Financial Innovations, 16(4): 290-302. http://dx.doi.org/10.21511/imfi.16(4).2019.25

Nguyen, M.L.T.; Bui, T.N.; Nguyen, T.Q. 2019. Relationships between Real Estate Markets and Economic Growth in Vietnam, Journal of Asian Finance, Economics and Business, 6(1): 121-128. http://doi.org/10.13106/jafeb.2019.vol6.no1.121

Nguyen, M.L.T.; Xuan, P.T.T; Bui, T.N. 2020. Causal relationship between banking system development and real estate market, Management Science Letters, 10(1): 41-52. http://doi.org/10.5267/j.msl.2019.8.017

$\mathrm{Ni}$, J.; Liu, J. 2011. The study in house market and stock market in China-HongKong-US, International Conference on Business and Economics Research, IACSIT Press, Kuala Lumpur, Malaysia, 71-75. Retrieved from: http://www.ipedr.com/vol1/16-B00027.pdf

Pesaran, M.H.; Shin, Y.; Smith, R.J. 2001. Bounds testing approaches to the analysis of level relationship, Journal of Applied Econometrics, 16(3): 289-326. https://doi.org/10.1002/jae.616

Pradhan, R.P.; Arvin, M.B.; Hall, J.H.; Bahmani, S. 2014. Causal nexus between economic growth, banking sector development, stock market development, and other macroeconomic variables: The case of ASEAN countries, Review of Financial Economics, 23(4): 155-173. https://doi.org/10.1016/j.rfe.2014.07.002

Shen, L. 2013. Financial dependence and growth: diminishing returns to improvement in financial development, Economics Letters, 120(2): 215-219. https://doi.org/10.1016/i.econlet.2013.04.018

Shen, C.H.; Lee, Y.H.; Wu, M.W.; Guo, N. 2016. Does housing boom lead to credit boom or is it the other way around? The case of China, International Review of Economics and Finance, 42: 349-367. https://doi.org/10.1016/j.iref.2015.10.008

Tsai, I.C.; Lee, C.F.; Chiang, M.C. 2011. The Asymmetric Wealth Effect in the US Housing and Stock Markets: Evidence from the Threshold Cointegration Model, The Journal of Real Estate Finance and Economics, 45: 1005-1020. https://doi.org/10.1007/s11146-011$\underline{9304-5}$

Tursoy, T.; Faisal, F. 2016. Causality between stock price and GDP in Turkey: An ARDL Bounds Testing Approach, Romanian Statistical Review, 64(4): 3-19. Retrieved from: https://econpapers.repec.org/article/rsrjournl/v 3a64 3ay 3a2016 3ai 3a4 3ap 3a3-19.htm

Zaman, K.; Izhar, Z.; Khan, M.M.; Ahmad, M. 2012. The relationship between financial indicators and human development in Pakistan, Economic Modelling, 29(5): 1515-1523. https://doi.org/10.1016/j.econmod.2012.05.013

Zhang, D.; Cai, J.; Liu, J.; Kutan, A.M. 2016. Real estate investments and financial stability: evidence from regional commercial banks in China, The European Journal of Finance, 6(1): 1-25. https://doi.org/10.1080/1351847X.2016.1154083

Zhao, S.X.B.; Zhan, H.; Jiang, Y.; Pan, W. 2017. How big is China's real estate bubble and why hasn't it burst yet?, Land Use Policy, 64: 153-162. https://doi.org/10.1016/j.landusepol.2017.02.024 


\section{ENTREPRENEURSHIP AND SUSTAINABILITY ISSUES}

ISSN 2345-0282 (online) http://jssidoi.org/jesi/

2020 Volume 8 Number 2 (December)

http://doi.org/10.9770/jesi.2020.8.2(58)

Assoc. Prof. Dr. My-Linh Thi NGUYEN is working at the Faculty of Banking and Finance, University of Finance and Marketing (UFM). The main areas of research are public policy, public finance, real estate market, financial development. With over 15 years of experience in research and teaching in the field of finance, she has published nearly 70 articles. In addition, she also attended many international conferences, conducted as the head of 6 ministerial-level and provincial-level projects in Vietnam, participated in the National Foundation for Science and Technology Development, and many other provincial and ministry level projects. Author and co-author of 8 books including textbooks and monographs. She has participated in review for many Journals.

ORCID ID: https://orcid.org/0000-0001-7475-2502

Toan Ngoc BUI is a lecturer at Faculty of Finance and Banking, Industrial University of Ho Chi Minh City (IUH), Vietnam. He holds a Master of Finance and Banking from Ho Chi Minh City Open University, Vietnam. Currently, he is pursuing a PhD at University of Finance - Marketing (UFM), Vietnam. His researches are in the fields of finance, real estate market and applied econometrics.

ORCID ID: https://orcid.org/0000-0002-0595-3172

Make your research more visible, join the Twitter account of ENTREPRENEURSHIP AND SUSTAINABILITY ISSUES: @Entrepr69728810

Copyright (C) 2020 by author(s) and VsI Entrepreneurship and Sustainability Center

This work is licensed under the Creative Commons Attribution International License (CC BY).

http://creativecommons.org/licenses/by/4.0/

(c) (i) Open Access 